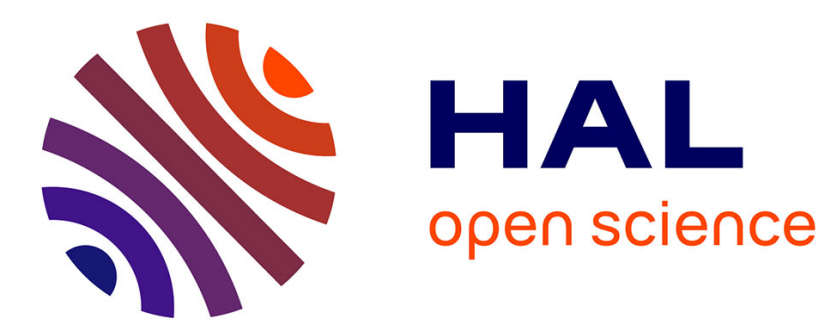

\title{
Modeling and simulation of Cohesion Policy funding and regional growth diffusion in an enlarged European Union
}

Sébastien Bourdin

\section{To cite this version:}

Sébastien Bourdin. Modeling and simulation of Cohesion Policy funding and regional growth diffusion in an enlarged European Union. Spatial Analysis and Location Modeling in Urban and Regional Systems, 2018. hal-02066300

HAL Id: hal-02066300

https://hal-normandie-univ.archives-ouvertes.fr/hal-02066300

Submitted on 13 Mar 2019

HAL is a multi-disciplinary open access archive for the deposit and dissemination of scientific research documents, whether they are published or not. The documents may come from teaching and research institutions in France or abroad, or from public or private research centers.
L'archive ouverte pluridisciplinaire $\mathbf{H A L}$, est destinée au dépôt et à la diffusion de documents scientifiques de niveau recherche, publiés ou non, émanant des établissements d'enseignement et de recherche français ou étrangers, des laboratoires publics ou privés. 


\title{
Modeling and simulation of Cohesion Policy funding and regional growth diffusion in an enlarged European Union
}

\author{
Sebastien Bourdin \\ Business School of Normandy, Métis Lab, \\ 9, rue Claude Bloch, 14052 Caen (France) \\ sbourdin@em-normandie.fr sebastienbourdin.com
}

\begin{abstract}
The dilemma between equity and competitiveness has created concerns about the future of redistribution of European regional policy funding. The objective of this chapter is to estimate the spatial expression of convergence and regional growth in the European Union. After contextualizing the EU enlargements of 2004 and 2007 , this study uses spatial statistics and the simulation platform GeoCells, the goal of which is to analyze two alternatives for future economic development of the $\mathrm{EU}$.
\end{abstract}

Keywords: cellular automata, cohesion policy, regional disparities, equity and competitiveness

Acknowledgements : This work is part of a collaborative project led with Bernard Elissalde, Dominique Goyat and Patrice Langlois, all of whom we wish to thank deeply. 


\section{Introduction}

On May 1st, 2004, the most important extension of the European Union (EU) in history took place. Ten countries became full EU members: in the north, the three Baltic States (Estonia, Latvia and Lithuania), the four countries of Central Europe (Hungary, Poland, the Czech Republic and Slovakia), a country of south-west area (Slovenia) and two islands (Cyprus and Malta). Two countries in South-East Europe (Bulgaria and Romania) integrated the EU on January 1st, 2007. Consequently, the level of prosperity in the EU declined significantly. However, because of the long process of transformation of post-soviet societies, this event was generally received with enthusiasm.

Numerous geographical issues arose from this policy of openness in the Central and Eastern European Countries (CEECs). What territorialized management of the cohesion policy was required with the arrival of ten new countries? The community economic frame was disrupted by the last two enlargements which provoked an unprecedented increase in the economic gap between developed regions and those lagging behind. This situation requires the member states to revise the objectives regarding cohesion in order to prevent increasing economic, social and territorial fragmentation of the Union.

The inclusion of the CEECs, countries with far less economic development than the poorest of the EU-15 (Italy, Spain, Greece and Portugal) reopened the question of the ability of Europe to promote socioeconomic and territorial cohesion. In light of the results of our simulations, our prospective approach proposes two possible scenarios of economic development for the EU of tomorrow by demonstrating the dilemma between equity and competitiveness (Lackenbauer 2006).

The purpose of this research is to understand the process of convergence by using the simulation platform GeoCells (Elissalde et al., 2009) coupled with spatial statistics. An application of this model demonstrates the economic performance of European regions according to the variation in aid granted by the European Union, as well as neighborhood effects. Taking into account the regional disparities, GeoCells analyzes European regions' relative positions from the angle of macroeconomic and budgetary indicators. The cellular automaton GeoCells allows an assessment of the overall effectiveness of regional policy and measures the influence of modification of granting rules.

The introduction of simulation and forecasting methods, along with spatial statistics, in EU regional policy debates is not an attempt to find the one and only response to the problem of European regions' unequal development. Instead, it suggests a range of credible options as a decision support tool for territorial solidarity - as well as economic and social cohesion - in a European space which is in perpetual evolution. Even though European regions belong to an interdependent group, they each have their specific trajectories, in which reaction times and pace of change vary strongly from one to another. These various trajectories build a European regional mosaic, making it difficult for policy makers 
to override initially planned regional policies (Cohesion Policy, Cohesion Funds, etc.) with budgetary adjustments. Overarching policies are enacted for these separate states/regions in their separate trajectories - but these policies may actually prevent, curtail, or disproportionately power certain trajectories, and in fact may disable newer "corrective" policy/fiscal mechanisms from assisting.

Methodologically, the GeoCells cellular automaton is based upon interactions between variables (e.g. time periods, growth rates in the GDP per head, flows of public investments) and three geographical levels (European level, national level and regional level). Due to the role of spatial interactions and contiguity effects in regional trajectories, in this research, a regional growth diffusion parameter was added to the above variables ratified by the European Commission. Though many regional growth models analyze the region as a stand-alone unit and ignore spatial interaction phenomena linked to proximity, neighborhood, or contiguity effects, the spatial dynamic parameter was added to the variables to underline the role of growth diffusion in regional development.

\section{What is the role of European regional policy in reducing disparities in the $\mathbf{E} \mathbf{U}$ ?}

The issue of the solidarity effort between Member States and regions (NUTS 2), as well as their adherence to the cohesion principles defined in the European texts and treaties, is at the center of the debates on European regional policy. The European Union's regional policy seeks to reduce structural disparities between EU regions, foster balanced development throughout the EU and promote real equal opportunities for all. Based on the concepts of solidarity and economic and social cohesion, it achieves this in practical terms by means of a variety of financing operations, principally through the Cohesion Policy (European Regional Development Fund (ERDF) and the Cohesion Fund). For the period 2007-2013, the European Union's regional policy is the EU's second largest budget item, with an allocation of EUR 348 billion. The objective of economic and social cohesion was introduced in 1986 with the adoption of the Single European Act. The policy was finally incorporated into the EC Treaty itself (Articles 158 to 162) with the Maastricht Treaty (1992).

The main question is in regard to the ability of Cohesion Policy to reduce disparities produced by the single market. How can we improve redistribution and territorial equity in a Union with low economic growth? In such an economic context, should we limit the solidarity efforts of wealthy countries or, on the contrary, increase it in order to accelerate the economic advancement of regions in an earlier stage of economic development?

The implicit deal between the EU and CEECs of opening new markets against the backdrop of the promise of a rising standard of living for relevant populations also implies that this development is achieved by offering newcomers Cohesion 
Policy. The results of EU policies in helping regions to economically advance are very difficult to assess accurately.

The evaluation of effectiveness of Cohesion Policy in promoting regional development raises methodological problems (Fayolle and Lecuyer 2000). Even if the distribution of Cohesion Policy is proportional to the economic development level, and regions lagging behind are catching up with wealthier regions, it is difficult to determine whether these outcomes are due to Cohesion Policy or other factors. In addition, there is no guarantee that the Cohesion Policy constitutes an explanatory factor of the regional convergence, even though their correlation is significant (ESPON Project 2.2.1. 2005). Indeed, we cannot rule out the possibility that a natural convergence process is simply an outcome of developmental progress.

Following the integration of ten CEECs in the EU in 2004, a debate on the development of the poorest regions emerged in the mid-2000s. The European Commission $(2006,2008$ a) hoped to invest massive resources in order to help them to develop more quickly. Nevertheless, Gorzelak et al. (2010) argues that the development through a massive injection of money in poor regions is ineffective. The transfer of more than EUR 1 billion euros did not meet expectations in southern Italy and former East Germany (ibid.). In addition, this method of massive investment has a perverse effect: it can create a situation in which the inhabitants of these regions become dependent upon aid they receive. Aghion and Cohen (2004) have shown that the only effective regional investment for poor regions is investment in education. However, these Funds are traditionally invested by the new Member Countries (a decision-making power which the EU has allowed) in other infrastructures such as transport. It is therefore understandable that policies in southern Italy or in Extremadura have not been fruitful.

The EU has to face to another structural obstacle. The EU must accept that the regional disparities in Eastern Europe have existed for centuries. It is very difficult to change these disparities in the time frame outlined in the Cohesion Policy program (i.e., 2000-2006 or 2007-2013). In Poland, for example, Coudroy de Lille (2009) highlighted the fact that regional contrasts and their spatial inscription were created in the nineteenth century. Stryjakiewicz (2007) also explains that metropolization has accentuated the regional disparities during economic transition. Thus, the CEECs are fragmented within their own borders, with disparities between cities and the countryside and between West and East. These differences are reinforced in the historical distribution of wealth, the post-Soviet transformation, the values of society and the efficiency of government.

Finally, before making decisions about fund allocation, it is necessary to consider where to invest. One might think that for ethical reasons, that aid should go to the poorest regions. However, studies show that investing in cities has much more of an impact than investing in rural communities (European Commission, 2008b). The analysis of successive generations of European aid to CEECs highlights the dilemma between equity (investment in rural areas with the goal of convergence) and competitiveness (investment in cities with the goal of growth). The economist Williamson (1965) studied the contradiction between a strong GDP growth rate and 
the increase of regional disparities. These studies were recently replicated in the EU by Ezcurra and Rapun (2006), who also came to the conclusion that an increase in financial support for CEECs would produce simultaneous convergences between the growth rates of CEECs and member countries of the EU, while increasing regional disparities within the CEECs. According to Bergs (2001) inter-regional convergence could take place over time, but at the expense of the national growth potential of new members. The latest report from the European Commission on Economic and Social Cohesion seems to confirm this prediction. If the disparities in the GDP per capita are decreasing between countries, they are increasing in each country. This is the case for both EU-15 Member States and the new Members States (European Commission, 2006 and 2008a; European Parliament, 2007 and 2008). Thus the problem of competitiveness and equity is posed (Fayolle and Lecuyer, 2000): should we help the least developed regions in order to help them to catch up?

Although the EU structural policy remains an important instrument of cohesion and solidarity at European level, its effectiveness at the EU regional policy level needs to be considered. However, because of the myriad of factors that come into play, it is impossible to assess categorically the true impact of the Cohesion Policy on European Spatial Planning (Durh et al., 2009) and territorial cohesion (Jouen, 2008; Kilper, 2009). It is also difficult to know what beneficiary regions would look like today if the funds had not been granted. It is for this reason that the modeling and simulation of EU Cohesion Policy based upon the configuration of regional economic disparities could contribute to the evaluation of european policies.

\section{Toward modeling the cohesion policy and its effects upon regional economic dynamics}

With the aim of investigating possible solutions for reducing the development gap - a gap which increased significantly with the progressive transition from 15 to 27 Member States in the European Union - we have developed a cellular automaton. The simulation platform GeoCells is use to determine under which conditions (in terms of budgetary redistribution settings) and according to which goals (of reduction, convergence, or adjustment), European solidarity policies could be effective. 


\subsection{The need for modeling and simulation to understand the issues of European regional policy}

Economic theory has various tools for clarifying and analyzing the issue of the role of European cohesion policy in the convergence process:

i) growth theories allow for an analysis of the mechanisms of economic growth as well as the outlook for divergence or convergence of economies;

ii) theories on geographic economy allow for a study of agglomeration mechanisms in economic activity and the spatial structure of economic disparities;

iii) econometric methods present tools for an evaluation of convergence phenomena in conjunction with cohesion policy.

With the development of simulation methods, several macroeconomic models have been created in order to understand the role of European regional policy in reducing regional disparities. Such simulations allow for an evaluation of what would have been the current situation of GDP in the absence of cohesion policy. These models also permit ex-ante or ex-post analyses and offer scenarios according to budgetary stance. Such a model undeniably has certain benefits. It is mainly for these reasons that the European Commission bases itself on work carried out within the framework of the HERMIN (Bradley et al., 1995, 2003 and 2007) and QUEST (Roeger et in 't Veld, 1997 et 2004 ; Varga et in 't Veld, 2011) models in its European Funds assessment reports. It draws some rather flattering estimations on the role of regional European policy in short term growth (Kelber, 2010) for the HERMIN model, whereas the QUEST model makes some slight references to its long term impact (Magnier, 2004).

Several publications have, however, highlighted their limitations. For Sjef Ederveen et al. (2002, 2006), the application of models such as QUEST et HERMIN only gives a glimpse of the potential effects of cohesion policy in the sense that these Funds have numerous parameters of efficiency. Nevertheless, according to these same authors, regional policy appears to be more successful in a environment which is conducive to growth. The example of the "Irish Miracle" is a clear illustration of this. Furthermore, Philippine Cour and Laurence Nayman (1999) note that the simulations only assess what the economic situation would have been in the absence of European regional policy (see for example "Panorama Inforegio", $n^{\circ} 33$, 2010) in a short term analysis. Finally, numerous underlying assumptions are made and their generality is problematical (Cappelen et al., 2003). For example, it is taken for granted that the collected Funds are systematically allocated to productive public investments, an assumption which is far from being systematically verified. The HERMIN model is based on the assumption that States are open economies (Bradley, 2002), which is not the case everywhere in Europe. One of the major limitations of this macroeconomic model is that it can only be applied on a national level. The regional declination is overlooked in this model due to insufficiently comprehensive 
databases. Moreover, amongst the assessments of the role of cohesion policy in regional growth and convergence, a number of authors (Le Gallo, 2004 ; Rey and Janikas, 2005 ; Ertur and Le Gallo, 2008) have demonstrated the role of the effects of neighborhood and spatial dependency on the efficiency of European Funds. The effects of diffusion of regional growth have not been taken into account in either model.

In this context, we consider that modeling by cellular automaton (Hill, 1993) enables a clarification of the issues of convergence and European regional integration. The model that we have developed allows for the effects of neighborhood and diffusion of regional growth to be taken into account. In addition, modeling by simulation is useful in that it reveals the processes and mechanisms (i) and serves as a decision support tool (ii).

(i) Cellular automaton simulation is constructive as it takes into account the complexity of the relationship between decision making (budgetary stance, duration of European regional policy programming periods), economic factors (growth and convergence) and spatial aspects (interaction between regions/Member States)

(ii) Simulation is helpful when it is not a question of finding the optimal solution but of exploring a wide range of possible scenarios in order to identify the parameters that would significantly improve the efficiency of European cohesion policy.

\subsection{GeoCells, a multi-layered hierarchical automaton}

GeoCells is a simulation platform based upon layers of geographic information. Its main engine is a meta-model based upon spatial agents or a topologic cellular agent. GeoCells is used to model the evolution of GDP per capita in the EU-27, and the simultaneous influence of different types of aid under the cohesion policy, and the effects of growth diffusion by neighborhood. The general operating principles for GeoCells are displayed in Figure 1.

The system is based upon a group of geographic information layers (Fig. 2). Each layer (EU (1); member-state (2); region (3)) consists of features from the same class. Each layer is made up of cells (EU, countries, regions). A cell's main function is to own, in addition to the feature's physical components (location, shape, size...), the knowledge of its neighborhood and above all a behavior dynamic.

Each layer owns behavior rules giving to the cells of its class the same function in the system (region, member-state, EU), properties and attributes (perimeter, surface, budget of the cell) and relations with cells from other layers of the system.

The system takes into account the hierarchical relationships existing between layers (Fig. 2); a region (Layer 1) belongs to a country (Layer 2) - inclusion link and a country is made up of regions - containing link.

Figure 1. GeoCells functioning principle 


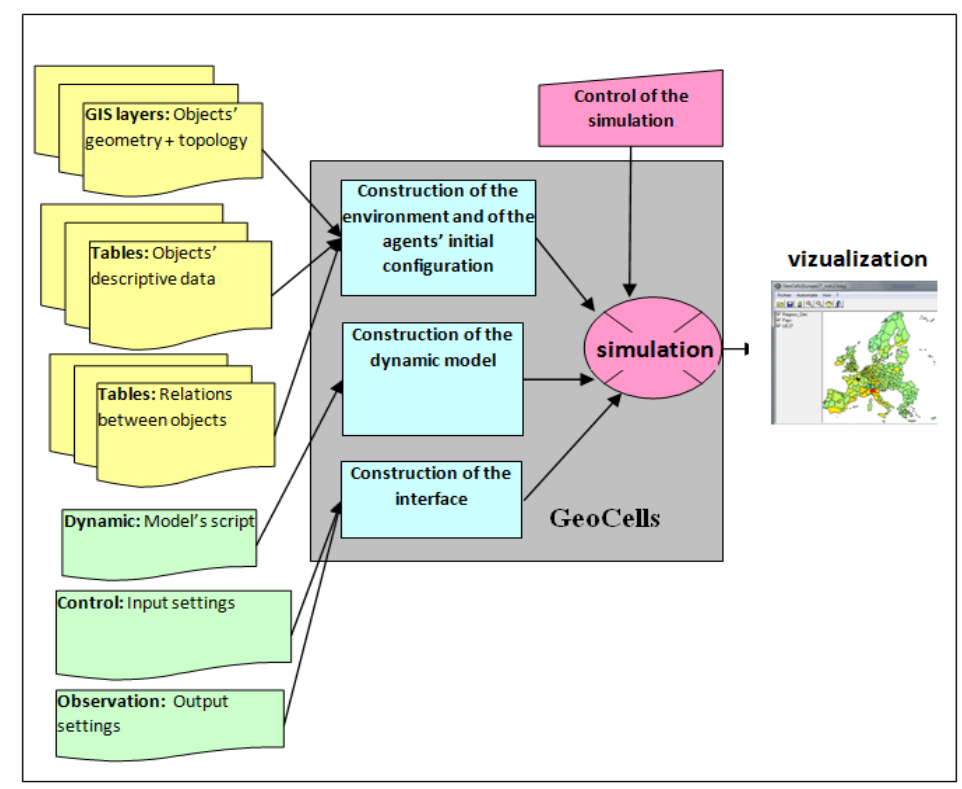

Figure 2. Hierarchy of cellular layers
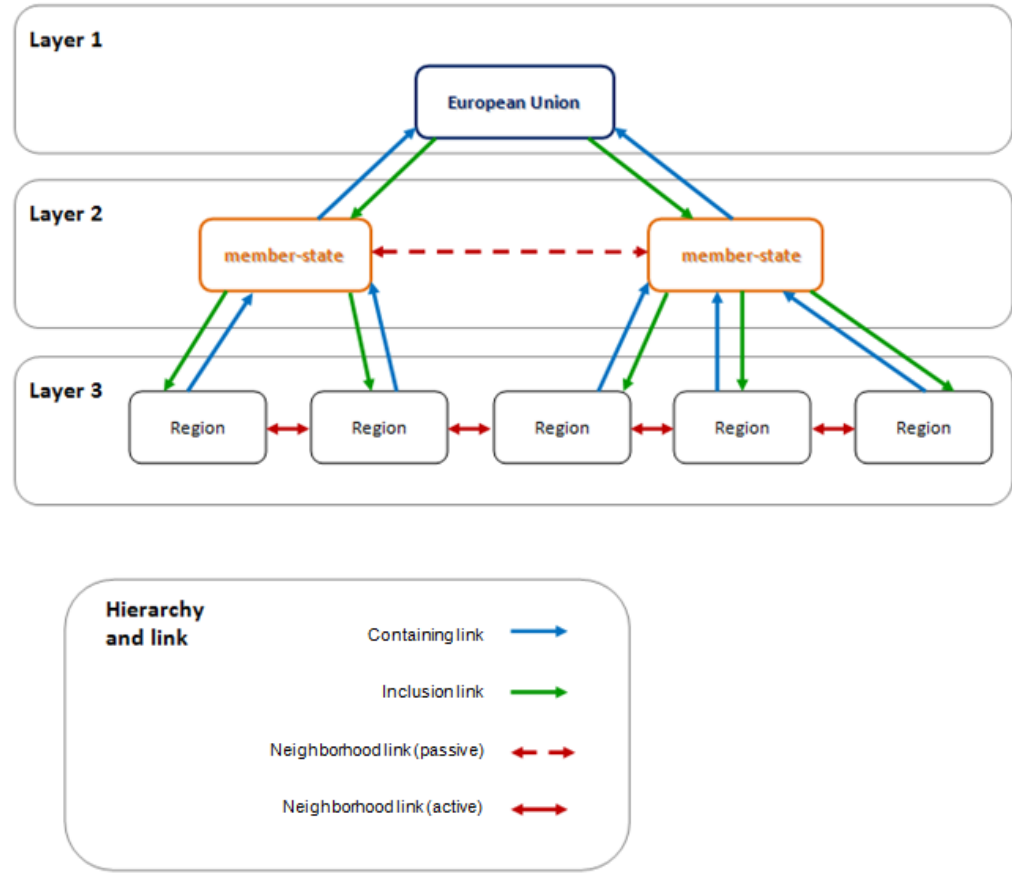

The generated automaton characteristics are described below: 
Cellular interactions: A cell layer interacts "naturally" with its sister cells (its topological neighbors) with its mother cell (above in the hierarchy) or its daughter cells (below in the hierarchy), but can also interact with cells of any other layer, through explicit links. These links represent cellular exchanges.

State: Each cell's state represents an attribute that is likely to change during the simulation. Each state has a semantics which can represent information (such as the budget of its neighbor) or an amount of material or energy (such as its own wealth, or population).

Phases of Life: One of the difficulties of this type of mechanism is to maintain the temporal coherence between all cellular layers. Every cell performs four steps when it receives inflow:

- Reading of its inputs (inflow from outside);

- Implementation of its program of action (behavior);

- Writing of its outputs (outflow exchange);

- Storage of its context (each cell must maintain at least the contents of the previous context). The context is defined here as the previous state of the cell and the recording of the state variables of neighboring cells.

Capacity - Every cell has its attributes (or state variables) but the rules of behavior are collective (because they are shared by all elements of its class). Each cell generates actions that depend upon its inputs and its state at a given time. The action taken is the result of a choice of the cell. This choice depends on the evaluation of the relevance of the rules of actions that may apply. In other words, the cell can have "smart" behavior comparable to that of an agent (we nevertheless retain the term cell).

Communication canals - A bidirectional communication canal exists to combine the system's multilayer nature. Each cell owns the input and output references relating to the canals that concern it. For this reason, the cell knows its environment and enters into dialogue with it.

\subsection{The possible simulation settings}

Given the data available for the group of regions NUTS2 of the EU-27, the model generated, as the main indicator, the variation in GDP per capita of each European region. Within Geocells, policy variables are adjusted for each simulation, while population remains constant. A user interface provides an opportunity at the beginning of the simulation for the user to enter a value for each policy variable. The settings which can be varied within Geocells are described below.

The Article 160 of the Treaty establishing the European Community (in its consolidated version in 2002) provides that the European Regional Development 
Fund (ERDF) is intended to help to redress the main regional imbalances in the Community. The ERDF therefore contributes to reducing the gap between the levels of development of the various regions and the extent to which the least favoured regions, including rural and urban areas, declining industrial regions, areas with a geographical or natural handicap, such as islands, mountainous areas, sparsely populated areas and border regions, are lagging behind. Rules of allocation of Cohesion Policy as defined in the Treaty have been implemented in Geocells. The GDP variation rate is, either specific to the region or identical to the group of regions of the same country or identical for the whole of EU. The terms of public intervention include the mechanisms relating to contributions (Countries and EU), to the aid linked to regional policy, such as eligibility thresholds $(75 \%$ of the average GDP per capita of the EU) for Cohesion Policy. The European budget weight is taken into account. The EU budget is stabilized around a threshold of $1 \%$ of the total European GDP (threshold reached since 1984 with the Single European Act). The EU had an agreed budget of EUR120.7 billion for the year 2007 and EUR 864.3 billion for the period 2007-2013, representing $1.05 \%$ of the overall wealth of the EU-27's. From this average budget, simulations were able to make the Eurropean budget weight vary from $0,5 \%$ to $3 \%$ of the EU total GDP. The principle of additionality between the States and the European Union in the Cohesion Policy financing was also taken into account. According to this principle, EU funds can only be paid in addition to a contribution from the member states, not instead of it. The variability of the relative importance of regional policy in the EU budget expenditures is also one of the simulation settings. The ERDF and the Cohesion Fund make up one of the largest items of the budget of the EU. The overall budget for the period 2007-2013 is EUR 271 billion and represent 30,4\% of total EU expenditures. In addition to these principles officially ratified by the Treaty establishing the European Community, we have added to our model a spatial dynamic parameter: the hypothesis of the role of spatial interactions and of contiguity effects in the regions' trajectories.

The diffusion by contact with neighboring regions, made possible by the functioning of the cellular automaton, is carried out therefore naturally in one way or another. With GeoCells, what is happening in the neighboring regions is not ignored. Several researchers (Baumont et al. 2002, Islam 2003; Le Gallo 2004; Rey and Janikas 2005; Dall'erba and Le Gallo 2008; Dall'erba et al. 2009; Dall'erba and Hewings 2009; Ertur and Le Gallo 2008) have shown that most studies consider the regions as isolated entities, as if their geographical location and their potential interlinkages were not important. However, the geographical distribution of growth phenomena at the regional level is rarely random: the economic performances of neighboring regions are often similar (Getis 1991). The impact of the unequal distribution of economic activities in space upon the territories' economic growth was underlined in particular by Baumont (1998). While a situation of spatial competition between activities and between territorial units exists, the taking into account of contagion, of mimicry phenomena linked to neighborhood effects proves to be necessary. 


\subsection{Growth-diffusion model for European regions}

We have attempt to model a complex diffusion process in real life by choosing a specific diffusion mechanism. The diffusion by contact with neighboring regions was highlighted especially by Elissalde et al. (2009) and Bourdin (2013) who has shown for example that regions of Central Europe (eastern Germany, the western parts of the Czech Republic, Slovakia, Hungary and Slovenia) have a low level of GDP per capita compared to the EU15 average, but a geographic environment which is more favorable than the regions further to the east in the EU. In this context, a catching-up of regions of Central Europe is explained in part by a growth diffusion process by neighboring. The proximity of regions of Central Europe to the border of the EU15 gives to these regions a high development potential compared to regions further east. This suggests that the distribution of regional growth occurs more neighbor to neighbor.

We will now clarify the unique diffusion model that we have used. The term $X_{i}$ represents the GDP of the region $i, P_{i}$ its population and $Y_{i}=X_{i} / P_{i}$ its GDP per capita at a moment $t$.

We present the following hypothesis. Each cell has the aim to homogenize, through time, its standard of living $Y$ in relation to its neighbors. The attempt to homogenize standard of living is the policy goal of the Territorial Cohesion. The main aim of the Territorial Cohesion policy is to contribute to a balanced distribution of economic and social resources among the European regions with the priority on the territorial dimension. This means that resources and opportunities should be equally distributed among the regions and their populations. But, in our model, standard of living is not capable of diffusing like a flow. It is through the variation of wealth $(X)$ symbolized by the GDP (by internal growth and by diffusion) or through the variation of population $(P)$ (also by internal growth or by migrations) that each region can work in order to achieve its goal. The diffusion mechanism only relies on the variation of $X$.

Another hypothesis is to consider that a small fringe close to the borderline (area in dotted line, Fig. 3) takes part in the diffusion of wealth, by the leveling-out of standards of living of the two neighboring border fringes (Fig. 3). Since we do not have any information on the spatial distribution of the populations inside a region, we must put forward the hypothesis of a uniform distribution. Consequently, we use a simple proportionality parameter, called the diffusion rate, the value of which can be set within the user interface. This parameter rate $k$ (of surface area, population, and wealth) is all at once, since we consider them as uniformly distributed over the region's surface area.

Figure 3. Practical implementation of growth-diffusion rate 


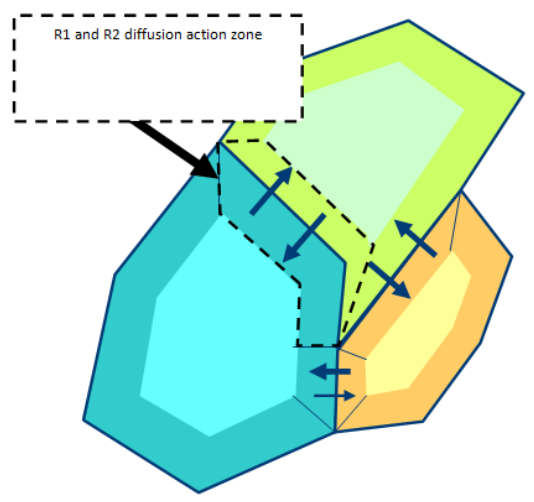

In order to model the diffusion between two regions $i$ and $j$, we then introduce the coefficient $k_{i j}$ which is the surface area's proportion $i$ matching the intersection between the border fringe defined by $k$ and the proportion $p_{i j}$ of its borderline land shared by the region $j$, defined by $p_{i j}=\frac{l_{i j}}{\sum_{k \in \operatorname{Vois}(i)} l_{i k}}$, where $l_{i j}$ is the borderline's length between $i$ and $j$.

We then have : $k_{i j}=k \cdot p_{i j}$

If the wealth on the two sides of the border fringe between $i$ and $j$ was evenly distributed like connected areas, we would obtain a leveled-out standard of living (which is not the average of the two previous standards), defined by:

$$
Y_{i j}=\frac{k_{i j} \cdot X_{i}+k_{j i} \cdot X_{j}}{k_{i j} \cdot P_{i}+k_{j i} \cdot P_{j}}
$$

We can then define the variation $d X_{i j}$ (positive if it emits or negative if it receives) of the diffusion from the region $i$ towards the region $j$ during a short lapse of time $d t$ as being proportional to the concerned population $\left(k_{i j} P_{i}\right)$ and proportional to the difference between the current standard of living $\left(Y_{i}\right)$ and the (local) aim of leveling-out $\left(Y_{i j}\right)$ of standards of living $i$ and $j$. This can be translated into the following equation:

$$
\frac{d X_{i j}}{d t}=K \cdot k_{i j} \cdot P_{i}\left(Y_{i}-Y_{i j}\right)
$$

The value of $K$ is set internally (since we can already play on $k$ ). 
By adding the border fringes of the region $i$, we note:

$$
d X_{i}=\sum_{j \in \operatorname{Vois}(i)} d X_{i j}
$$

One should notice that this diffusion is, by construction, preservative of the mean $\sum_{i=1}^{n} X_{i}$ (because one can verify easily that for any couple $(i, j)$ we have: $\left.d X_{i j}+d X_{j i}=0\right)$

Moreover, the variable $X_{i}$ is subjected to an a priori exponential internal growth, $\frac{d X_{i}}{d t}=C_{i} X_{i}$

Internal growth is adjustable, either individually region by region through the attribute table, either on the whole as being the same for all regions with the help of a setting determined by the user within.

The final growth-diffusion equation is thus given by:

$$
X_{i}(t+d t)=X_{i}(t)+\left(C_{i} \cdot X_{i}(t)+K . k_{i j} P_{i}\left(Y_{i}-Y_{i j}\right)\right) d t
$$

The lapse of time for the discretization of growth and diffusion processes are small compared to redistributing flows, because they correspond to continuous processes. We have selected the month as lapse of time, that also matches the time unit that we chose, so $d t=1$. ( $C_{i}$ is then the twelfth of the annual growth rate).

The equation with this lapse of time is then written:

$$
X_{i}(t+d t)=\left(1+C_{i}\right) X_{i}(t)+K . k_{i j} P_{i}\left(Y_{i}-Y_{i j}\right)
$$

\section{Europe 2025 : Which scenario from which policy?}

To assess the weight of political cohesion in regional trajectories, simulations were performed with the GeoCells platform. These simulations were based on the one hand on the settings of allocations Funds and, on the other hand on neighborhood effects. The two scenarios presented below ask questions about the effectiveness of the cohesion policy and the dilemma between competitiveness and equity. This dilemma can be read in the Treaty of Rome (1957) and the Single European Act (1987) where it says that the EU has to support the growth and the job creation in Member states and least developed regions.

The first scenario (simu 1) is the one of free competition between regions without the intervention of Cohesion Policy (table 1). It is tantamount to abolishing 
European "interventionism" and to "renationalizing" aid, just as recommended in the Sapir Report. "An Agenda for a Growing Europe", also called The Sapir Report, is a report on the economy of the European Union edited by a panel of experts under the direction of André Sapir and published in July 2003. The report follows an initiative by Romano Prodi, President of the European Commission, notably to analyze the Lisbon Strategy. According to the experts of this report, Cohesion Policy and other community interventions do not contribute in an easily measurable way to the convergence of the regions. The results obtained by the countries of the EU remain dependent on their good governance, which leads the experts of this report to write the following recommendation: "there is a solid argument for the new EU convergence policy to focus on countries, rather than on regions". Considering the European budgetary constraints, the report recommends an important reduction of Funds intended for the Cohesion Policy. The simulations include a low percentage of Cohesion Policy in the EU budget. Almost all regions can apply for the Cohesion Policy because the threshold of allocation of Cohesion Policy of $90 \%$ of the average GDP per capita of the EU. We observe that disadvantaged regions catch up slowly and the sigma convergence indicates divergence ${ }^{1}$. The distribution of wealth is more non-egalitarian than the scenario of equity.

The second scenario (Simu 2) has as its goal territorial equity (Table 1). Territorial equity includes ideas of parity of treatment, equality of access, and, more generally, solidarity between regional organizations in terms of public action, especially by implementing corrective measures as far as resources and facilities are concerned. The scenario consists of endowing each region with a measure of autonomy and the necessary conditions for development. Cohesion Policy are used alone, by increasing the percentage devoted to regional policy to $35 \%$ of EU budget, and by retaining the actual threshold of allocation of Cohesion Policy to $75 \%$ of the average GDP per capita of the EU.

Table 1. Indicators in Scenarios of Cohesion Policy in Europe in 2025

\begin{tabular}{lcc}
\hline Scenario: & Simu 1 : & Simu 2 : \\
& Competitiveness & Solidarity \\
\hline
\end{tabular}

\footnotetext{
${ }^{1}$ The sigma convergence refers to a reduction in the dispersion of levels of income across economies. Here there is an increase of disparities among regions because of positive result $(0,0021)$.
} 


\begin{tabular}{|c|c|c|}
\hline $\begin{array}{l}\text { - Cohesion Policy - per- } \\
\text { centage of the EU } \\
\text { budget }\end{array}$ & $10 \%$ & $35 \%$ \\
\hline $\begin{array}{l}\text { - Threshold of alloca- } \\
\text { tion of Cohesion Policy } \\
\text { (GNI/gross national in- } \\
\text { come as percent of EU } \\
\text { average) }\end{array}$ & $90 \%$ & $75 \%$ \\
\hline - Beta convergence & $-0,2654$ & $-0,6818$ \\
\hline - Sigma convergence & 0,0021 & $-0,0012$ \\
\hline - GDP diffusion rate & $30 \%$ & $10 \%$ \\
\hline - Gini index & 0,21 & 0,14 \\
\hline - Moran index & 0,43 & 0,37 \\
\hline - Doctrine & Liberalism & Planned economy \\
\hline \multirow{2}{*}{$\begin{array}{l}\text { - Priorities for the cohe- } \\
\text { sion policy }\end{array}$} & Competitiveness & Convergence \\
\hline & & $\begin{array}{c}\text { Integration of the less economically de- } \\
\text { veloped regions }\end{array}$ \\
\hline - Public policies & Renationalization of aid & Increase Cohesion Policy total budget \\
\hline $\begin{array}{l}\text { - Mechanism for pro- } \\
\text { moting cohesion }\end{array}$ & $\begin{array}{l}\text { Liberalization and competition in- } \\
\text { creased }\end{array}$ & Strong regulation \\
\hline
\end{tabular}

The measure of convergence based on the evolution of the standard deviation (sigma convergence) gives the most valuable result for the scenario of equity based upon increasing the budget for regional policy, and the prospect of catching-up (beta convergence) is more credible with the scenario of equity as well. With this policy orientation, every region of each country reacts positively to territorial solidarity programs. In accordance with the results in terms of beta and sigma convergence, simulation 2 brings out a better result in terms of Territorial Cohesion, mitigating significatively regional disparities across $\mathrm{EU}$.

The cartography of these scenarios gives concrete expression to the impact on geographic distribution of growth chosen by each parameter setting (Fig. 4). We have measured local concentrations through the Getis-Ord statistics. This index allows the identification of spatial clusters (or "local pockets"). A positive value will indicate a spatial concentration of GDP per capita (called a "hot spot"), while a negative value of that index is associated with spatial concentration of low value of GDP per capita (a "cold spot"). Two main patterns of clusters can be shown. Within the competitive scenario, the "Pentagon" (cluster of prosperous regions) and regions bordering this cluster are strongly linked to each other; unfortunately many regions of formerly socialist countries remain far behind. This scenario produces the phenomena of the clustering of prosperous regions very often from metropolitan regions (South of England, Parisian Basin, North West of Italy) whereas poor regions do not manage to progress of their backwardness. Representative of a nonegalitarian growth, this phenomena reveals a certain effectiveness at national level, 
but establishes itself as less homogeneous at European level. Growth takes place by clusters of regions, but the development gaps are not on the whole being closed (low beta convergence). On the other hand, the scenario of equity highlights the progress of the convergence of GDP. It allows CEECs regions to catch up while allowing the Pentagon to continue to grow. This hypothesis gives a negative sigma convergence with a low dispersion of incomes between regions, since poorer regions saw their GDP per capita rise, but, not at the same rhythm. CEECs regions located closest to the former Iron Curtain seem to be progressing faster.

Fig. 4. Cartography of Scenario 1 and 2 - Spatial statistics
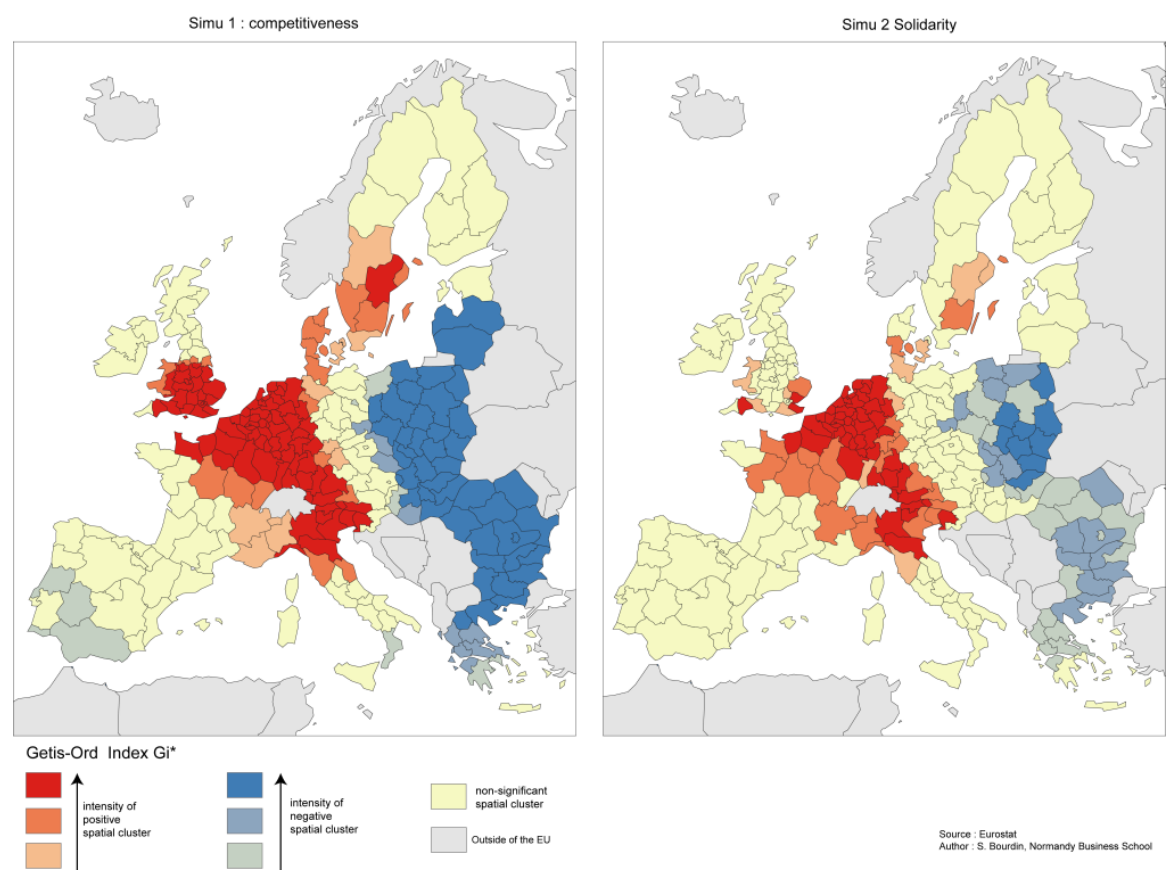

In addition to the two indicators of convergence (beta and sigma) - in theory complementary and often referenced in the literature in regard to regions' convergence - the introduction of a contiguity-based growth propagation variable changed the expected scenarios which stood as a basis for EU policies. This introduction of spatial interaction by neighborhood transforms the deterministic projections of the EU policies into a system of regional units reacting according to a multi-scalar complexity. The process accounting neighborhood effects reveals the potential for a spatial diffusion process to occur under the assumptions given in each scenario.

The budget of the European regional policy has always been the second largest item of expenditure in the EU, far behind that of the Common Agricultural Policy. 
With the new programming period 2007-2013, the budget was brought to the forefront because of the efforts related to the 2004 and 2007 enlargements. Achieving competitiveness of the regions included in the Lisbon strategy requires building development strategies that enhance regional strengths and overcome weaknesses and regional gaps. To meet the challenges of globalization, the EU has included the concept of competition in the 2007-2013 programming period for the Cohesion Policy. Meanwhile, the EU continues to pursue its objective of solidarity between regions and countries. This dilemma can be answered by the concept of polycentric development ${ }^{2}$. This concept refers to a development of a polycentric and balanced urban system, and strengthening of the partnership between urban and rural areas, so as to create a new urban-rural relationship. It includes the promotion of integrated transport and communication, which support the polycentric development of the EU territory, so that there is gradual progress towards parity of access to infrastructure and knowledge. Implicitly, this principle implies the presence of "centers" that spread their prosperity to their neighborhoods (hence the need to introduce neighborhood effects in GeoCells) while continuing to help the less economically developed regions to be competitive vis-à-vis the wealthier ${ }^{3}$. This would combine greater European competitiveness with an increase in prosperity of peripheral regions in order to catch up. The spatial dimension of European public action is an opportunity to resolve these contradictions. The territorialization of public policies for regional development (which consists of differentiating policy applications for different regions) coupled with a polycentric planning can allow a difficult compromise between equity and competitiveness.

\section{Conclusion}

The objective of this chapter was not to provide an answer on how the Cohesion Policy should be used (axiological neutrality) but to clarify issues for the future of European cohesion policy. This clarification is necessary to understand the geographic organization of economic inequality and regional development. The two scenarios that have been demonstrated in this study show that the political choices between equity and competitiveness have a profound impact on territorial development. These choices in structural funding investment produce very different economic and spatial configurations. Not only the political orientation can influence outcome, but other factors can have a significant impact on territorial cohesion. Both pre-determined (i.e. programming policies, historical factors) and random (neighborhood effects, diffusion of regional growth) factors affect the dynamics of regional growth and convergence. Because each region has a unique trajectory

\footnotetext{
2 "Promote a harmonious and well-balanced development of the EU's territory", European Commission (1998).

3 Sapir Report advocates this but stopping aid to regions in an earlier stage of economic development, thus not allowing these regions to be competitive vis-a-vis the wealthiest
} 
based not only upon Cohesion Policy but also upon random factors, it is impossible to directly link Cohesion Policy alone to regional economic growth.

At this stage of our research, it would be helpful to use an input-output model as an extension for future work. The input-output model would represent the sectoral diffusion of the funding (underlying processes) and the simulation could represent the resulting geographic diffusion/interactions. The goal would be to explore the logical consequences of assumptions based on neighborhood effects, to complete them with the simulation results so get to know the reality and act more effectively on it.

\section{References}

Aghion, P., \& Cohen, E.. (2004). Education et Croissance. Paris : La Documentation Française.

Baumont, C. (1998). Economie géographique et intégration régionale : Quels enseignements pour les Pays d'Europe Centrale et Orientale ? LATEC-Economics Working Paper (1991-2003), 199811 .

Baumont, C., Ertur, C., \& Le Gallo, J. (2002). The European Regional Convergence Process, 1980 1995: Do Spatial Regimes and Spatial Dependence Matter? Economics Working Paper Archive Econometrics 0207002.

Bergs, R. (2001). EU Regional and Cohesion Policy and Economic Integration of the Accession Countries. Discussion Paper, Policy Research \& Consultancy.

Bourdin, S. (2013). Une mesure spatiale locale de la sigma-convergence pour évaluer les disparités régionales dans l'Union européenne, Région et Développement, 37.

Bradley, J. et Untiedt, G. (2007). Do economic models tell us anything useful about Cohesion Policy impacts? A comparison of HERMIN, QUEST and ECOMOD. Working Paper, 3, GEFRA - Gesellschaft fuer Finanz- und Regionalanalysen.

Bradley, J., Morgenroth, E. et Untiedt, G. (2003). Macro-regional evaluation of the Structural Funds using the HERMIN modelling framework. ERSA Congress University of Jyväskylä - Finland.

Bradley, J. (2002). An Examination of the Ex-post Macroeconomic Impacts of CSF 1994-99 on Objective 1 Countries and Regions. Greece, Ireland, Portugal, Spain, East Germany and Northern Ireland. Final Report, ESRI \& GEFRA, Dublin.

Bradley, J., Herce, J-A. et Leonor, M. (1995). Modelling in the EU periphery : The HERMIN project. Economic Modelling, 12(3), 219-22.

Cappelen, A., Castellacci, F., Fagerberg, J. et Verspagen, B. (2003). The Impact of EU Regional Support on Growth and Convergence in the European Union. Journal of common market studies, 41, 641-644. 
Coudroy de Lille, L. (2009). Les nouveaux territoires polonais. In Jean, Y., \& Baudelle, G. (Ed.), L'Europe, aménager les territoires, Paris : Armand Collin.

Cour, P. et Nayman, L. (1999). Fonds Structurels et disparités régionales en Europe. La lettre $d u$ CEPII, 177 .

Dall'erba, S., \& Le Gallo, J.. (2008). Regional convergence and the impact of European Cohesion Policy over 1989-1999: a spatial econometric analysis. Papers in Regional Science, 87, 219-244.

Dall'erba, S. and Hewings, G.J.D. (2009). European regional development policies: The trade-off between efficiency-equity revisited. Connections, 5, 73-84.

Dall'erba, S., Guillain, R., and Le Gallo, J. (2009). Impact of Cohesion Policy on regional growth: How to reconsider a 9-year-old black box. Région et Développement, 30, 77-100.

Dühr, S., Nadin, V., Colomb, C. (2009). European spatial planning: territorial development, cooperation and EU spatial policy. Londres : Routledge.

Ederveen, S., Groot, H.L.F. et Nahuis, R. (2006). Fertile Soil for Structural Funds? A Panel Data Analysis of the Conditional Effectiveness of European Cohesion Policy. Kyklos, 59(1), 17-42.

Ederveen, S. et Gorter, J. (2002). Does European Cohesion Policy Reduce Regional Disparities? An Empirical Analysis. CPB Working Paper, 15, CPB Netherlands Bureau for Economic Policy Analysis.

Elissalde, B., Goyat, D., \& Langlois, P. (2009). GeoCells model : European Cohesion Policy and regional interactions, which convergences for the European regions? Revue électronique Cybergeo. doi : 10.4000/cybergeo.22388

Ertur, C., and Le Gallo, J. (2008). Regional growth and convergence : heterogenous reaction versus interaction in spatial econometric approaches. oai : hal.archives-ouvertes.fr:hal-00463274.

ESPON Project 2.2.1. (2005). The territorial effects of the Cohesion Policy, Final report. Eschsur-Alzette : Espon Coordination Unit and Nordregio.

European Commission (1998). Resolution on regional planning and the European Spatial Development Perspective, Brussels.

European Commission. (2006). Cohesion policy and cities : the urban contribution to growth and jobs in the regions, Brussels.

European Commission. (2008a). Growing regions, growing Europe, 5th cohesion report. Brussels.

European Commission. (2008b). Green Paper on territorial cohesion. Brussels : DG Regio.

European Parliament. (2007). Regional disparities and cohesion : what strategies for the future? Brussels.

European Parliament. (2008). Shrinking regions : a paradigm shift in demography and territorial development, Brussels.

Ezcurra, R. \& Rapún, M. (2006). Regional disparities and national development revisited, the case of western Europe. European Urban and Regional Studies, 13 (4), 355-369. 
Fayolle, J., \& Lecuyer, A. (2000). Croissance régionale, appartenance nationale et fonds structurels européens. Un bilan d'étape. Revue de l'OFCE, 73, 161-196.

Getis, A. (1991). Spatial interaction and spatial autocorrelation: a cross-product approach. Environment and Planning, 23, 1269-1277.

Gorzelak, G., Maier, G., \& Petrakos G. (2010). Integration and transition in Europe: the economic geography of interaction. London : Routlege.

Islam, N. (2003). What have we learnt from the convergence debate ? Journal of Economic Surveys, 17, 309-362.

Jouen, M. (2008). La cohésion territoriale, de la théorie à la pratique. Notre Europe.

Kelber A. (2010). La politique de cohésion et les nouveaux États membres de l'Union européenne. Bulletin de la Banque de France, 181 (3), 1-13.

Kilper, H. (Ed.). (2009). New disparities in spatial development in Europe. German Annual of Spatial Research and Policy, Springer.

Lackenbauer, J. (2006). Equity, efficiency, and perspectives for cohesion policy in the enlarged European Union. BERG Velag, Bamberg.

Le Gallo, J. (2004). Space-time analysis of GDP disparities among European regions : a Markov chains approach. International Regional Science Review, 27, 138-163.

Magnier, P. (2004). Fonds structurels européens et politiques régionales. Commissariat général du plan, La Documentation française.

PANORAMA (2010). Evaluating Regional Policy : Insights and results. Inforegio, 33.

Rey, S.J., \& Janikas, M.V. (2005). Regional convergence, inequality and space. Journal of Economic Geography, 5 (2), 155-176.

Roeger, W. et in 't Veld, J. (1997). QUEST II. A Multi-Country Business Cycle and Growth Model. European Economy - Economic Papers, 123, Directorate General Economic and Monetary Affairs, European Commission.

Roeger, W. et in 't Veld, J. (2004). Some selected simulation experiments with the European commission's QUEST model. Economic Modelling, 21(5), 785-832.

Sapir J., Aghion P., Bertola G., Hellwig M., Pisani-Ferry J., Rosati D., Viñals J., Wallace H., Buti M., Nava M. et Smith P.M. (2003). An Agenda for a Growing Europe: The Sapir Report, ed. Oxford University Press, Oxford.

Stryjakiewicz T. (2007). La nouvelle géographie de la Pologne dans le contexte de la transition économique et sociale et de l'élargissement de l'Union européenne. L'Information Géographique, $71(4), 100-120$

Varga, J. et in 't Veld, J. (2011). A model-based analysis of the impact of Cohesion Policy expenditure 2000-06: Simulations with the QUEST III endogenous R\&D model. Economic Modelling, 28(1-2), 647-663. 
Williamson, J. G. (1965). Regional Inequality and the Process of National Development : A Description of the Patterns, Economic Development and Cultural Change, 13, 1-84. 